Pamiętnik Literacki 2018, 3, s. 35-50

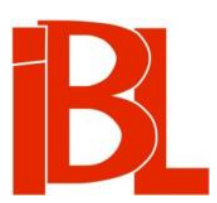

\title{
W poszukiwaniu nowego spojrzenia. Proza Stanisławy Przybyszewskiej między awangardą a modernizmem wernakularnym
}

Monika Świerkosz 
Pamiętnik Literacki CIX, 2018, z. 3, PL ISSN 0031-0514

DOI: $10.18318 / \mathrm{pl} .2018 .3 .3$

MONIKA ŚWIERKOSZ Uniwersytet Jagielloński, Kraków

\section{W POSZUKIWANIU NOWEGO SPOJRZENIA PROZA STANISŁAWY PRZYBYSZEWSKIEJ MIEDZY AWANGARDĄ A MODERNIZMEM WERNAKULARNYM}

\section{Tandetne wytwory rewolucjonistki?}

Pod koniec lat siedemdziesiątych XX wieku Anna Bojarska w taki oto sposób tłumaczyła powody triumfalnego (choć krótkotrwałego) powrotu Stanisławy Przybyszewskiej do obiegu literackiego:

Połączenie dorobku pisarskiego, który w pewnym momencie - w kilkadziesiąt lat po śmierci autorki - zaczął nagle budzić zainteresowanie, podziw, sensację, z czytankowym schematem tragicznego życia nie rozpoznanego geniusza nieoczekiwanie okazało się atrakcyjne ${ }^{1}$.

Przyczynił się do tego niewątpliwie sukces teatralnej adaptacji Sprawy Dantona w reżyserii Andrzeja Wajdy (1975), a następnie jego filmowej wersji z 1984 roku, z Gérardem Depardieu w roli Robespierre'a. Nobilitowana dzięki wybitnym dziełom uznanego reżysera, nazwana przez niego „skarbem nieodkrytym”, Przybyszewska postawiona została w jednym szeregu $z$ najwybitniejszymi polskimi dramatopisarzami: Różewiczem, Mrożkiem, Gombrowiczem. Również 3-tomowa edycja jej listów (wydawanych w opracowaniu Tomasza Lewandowskiego w latach 1978-1985) ${ }^{2}$ oraz wspaniałe fragmenty Transgresji Marii Janion, poświęcone Przybyszewskiej ${ }^{3}$, pokazywały ją jako osobowość wyjątkową, złożoną, skonfliktowaną wewnętrznie, samotnie dźwigającą ciężar swoich wyborów życiowych i artystycznych. Tak oto utrwalił się wizerunek „genialnej, choć zapomnianej córki smutnego szatana”, wielkiej dramatopisarki o złamanym (w znacznej mierze przez własnego ojca oraz

1 A. Bojarska, Andrée Lynne. (Proza Stanisławy Przybyszewskiej). „Przegląd Humanistyczny” 1978, nr 11, s. 101.

2 S. Przybyszewska, Listy. Oprac., wstęp, przypisy T. Lewandowski. T. 1-3. Gdańsk 1978-1985. Do pozycji tej odsyłam skrótem L. Pierwsza liczba po skrócie, po łączniku, wskazuje tom, następna - stronicę.

Korespondencja Przybyszewskiej (przedstawiona w wyborze) okazała się również atrakcyjna dla czytelnika zagranicznego - zob. J. Ko si c ka, D. G e ro uld, A Life of Solitude. Stanisława Przybyszewska: a Biographical Study with Selected Letters. Evanstone, Ill., 1989 (wyd. 1: 1986).

3 M. Janion, Pleśń i rdza. W zb.: Transgresje. T. 3: Osoby. Wybór, oprac., red. M. Janion, S. Rosiek. Gdańsk 1984.

4 Nawiązuję do tytułu popularnej, zbeletryzowanej biografii pisarki pióra K. Kolinnskiej (Córka smutnego szatana. Warszawa 1993), powstałej, co prawda, nieco później, ale wyrosłej z tej samej 
uwarunkowania ekonomiczne) życiorysie - wizerunek atrakcyjny z różnych powodów zarówno w obiegu wysokoartystycznym, jak i popularnym.

Wśród materiałów pozostawionych przez Przybyszewską i przechowywanych przez poznański oddział Archiwum PAN ${ }^{5}$ nie odnajdziemy jednak żadnych więcej prób dramatycznych, lecz wyłącznie prozę - dłuższe i krótsze nowele, powieści i mikropowieści, najczęściej nieukończone i o tematyce współczesnej, z dominującymi wątkami romansowym oraz sensacyjnym. W utworach tych pojawiają się postaci Nowych Kobiet i Nowych Mężczyzn, ukazane na tle typowych dla nowoczesności przestrzeni miast: ulic, po których mkna pierwsze samochody, hotelowych pokoi, sal balowych, dancingów, willi i biur. Ekstrawagancko brzmiące imiona: Luko (tak naprawdę: Charles Karsen), Nina, Eda, Lu, Charlie, Cara, Zand, świat wielkich pieniędzy, sztuki, ambicjonalnych walk, intryg, spektakularnych bankructw i melodramatycznych zdarzeń. Te literackie próbki wydają się tak dalekie od szlachetnej wzniosłości rewolucyjnych dramatów, jak grafomańska pisanina różni się od arcydzieła, toteż przy ich odkrywaniu towarzyszył badaczom pewien rodzaj rozczarowania.

Bojarska określiła to wprost: owe krótkie formy prozatorskie „trącą szmira”, mimo iż kompozycja i fabuła są dopracowane, a przesłanie dalekie jest od konserwatyzmu (i konformizmu) literatury masowej. Najwyraźniej Przybyszewska popełniła „błąd w sztuce”: po pierwsze, przykrawając swój talent buntowniczki literackiej do gustów epoki, po drugie - eliminując ze swoich utworów prawdziwe życie, o którym pisarka dowiadywała się $z$ gazet i powieścideł wydawanych w popularnej serii Tauchnitza. W efekcie powstały dzieła niewiarygodne (jak kopie kopii) i pretensjonalne, bo próbujące usilnie stać się czymś więcej niż literaturą masową. To brak swobody twórczej zmusił Przybyszewska, żyjąca z dala od literacko-towarzyskich sieci wpływów, do produkowania „okaleczonych” i sfałszowanych fabuł, które nadawałyby się (jej zdaniem) do publikacji ${ }^{6}$.

Nieco inaczej widziała to Ewa Graczyk, która choć zgodziła się z Bojarską w ocenie wpływu „hollywoodzkiej wyobraźni” na kształt prozy Przybyszewskiej, to jednak przyczyny jej fiaska artystycznego upatrywała raczej w pełnej sprzeczności osobowości pisarskiej niż tylko w ekonomiczno-środowiskowych barierach. Totalny model literatury projektowany przez autorkę Sprawy Dantona - chłód emocjonalny, nadludzka wielkość, racjonalność, geometryczna czy wręcz mechaniczna precyzja formy - wyraźnie kontrastują $z$ romansowymi schematami fabularnymi utworów prozatorskich oraz pragnień, jakie one skrywaja. Badaczka pyta retorycznie:

Jak ustosunkować się do złego gustu tych marzeń, do ich „warstwy kuchennej”, warstwy wyobraźni popularnej, masowej? [...] Co zrobić z „biurówką”, która w Przybyszewskiej niewątpliwie tkwiła?7

fascynacji owym „czytankowym”, tj. melodramatycznym schematem życia Przybyszewskiej, o którym wspomina Bojarska.

5 Materiały Stanisławy Przybyszewskiej zostały przekazane przez Stanisława Helsztyńskiego Polskiej Akademii Nauk i obecnie znajdują się w poznańskim oddziale tej instytucji. Kilka lat temu materiały pisarki wyodrębniono ze spuścizny Helsztyńskiego i oznaczono sygnaturą (PAN P-III-52 a).

6 B ojar s ka, op. cit., s. 107. Autorka wyraźnie podkreśla ekonomiczne tło konfliktu między potencjałem artystycznym Przybyszewskiej a „,horyzontem oczekiwań” ówczesnego czytelnika (czytelniczki) prasy popularnej oraz wydawcy.

7 E. Gra czy k, Ćma. O Stanisławie Przybyszewskiej. Warszawa 1994, s. 136-137. To pogardliwe 
Istotnie, proza ta może rozczarowywać, zwłaszcza czytelników spodziewających się odnaleźć w niej mroczną głębię i tragizm dzieł Kafki, z którym Przybyszewska bywała zreszta zestawiana. Pytanie o to, dlaczego polska pisarka nie stworzyła czegoś podobnego do znakomitej prozy autora Procesu, pojawia się na marginesach Transgresji ${ }^{8}$. Taki sposób patrzenia na nowele i mikropowieści Przybyszewskiej nie jest bezpodstawny i znajduje potwierdzenie również w wypowiedziach jej samej zachęcała ona wręcz do krytycznej oceny jej utworów prozatorskich jako nieudanych błahostek. Wielokrotnie wyrażała w listach lekceważenie zarówno dla formy opowiadania, jak i jego miłosnej lub kryminalnej fabuły. Czy nie powinniśmy jednak być bardziej podejrzliwi wobec autorskich gier Przybyszewskiej, która zmagania z owymi „błahostkami” uczyniła w pewnym momencie idée fixe swojego pisarstwa? Może więc motyw niechęci do przeklętego gatunku short story, obsesyjnie powracający nie tylko w listach, ale i w autotematycznych fragmentach samych opowiadań, jest świadectwem literackiej walki o „formę”, nie zaś obojętności pisarki wobec sztuki prozatorskiej?

W tekście „Święty Charlie Chaplin” Lena Magnone zwróciła uwagę na fascynację Przybyszewskiej zarówno przedwojennym kinem awangardowym (niemieckim i radzieckim ekspresjonizmem), jak i wczesnymi hollywoodzkimi superprodukcjami. Przekonująco pokazała głębokie i twórcze związki między poetyką utworów prozatorskich Przybyszewskiej a poetyką filmów noir ${ }^{9}$. Jeśli za pomoca tego klucza „przeczytamy jej nowele i powieści, zwłaszcza te o tematyce współczesnej, traktując rozbudowane opisy gwałtownych emocji i monologi wewnętrzne jako rodzaj partytury dla aktora, ze zwykle rzadkimi - tak rzadkimi jak plansze w niemym kinie -

określenie „biurówka” pochodzi od samej pisarki. Natomiast badaczka motywuje porażkę projektu artystycznego autorki Sprawy Dantona wielopoziomowo: klasowo, biograficznie (i genderowo), geopolitycznie oraz artystycznie, widząc przyczyny jej niepowodzenia w zarzucanym jej z pozycji nowoczesnych anachronizmie. Przybyszewską identyfikowano bowiem z młodopolszczyzną, mimo iż pisarka akcentowała na różne sposoby swój negatywny stosunek do literackiego dziedzictwa ojca, niemniej uwikłana w dialog krytyczny z młodopolskim ekspresjonizmem wciąż w pewnym sensie „cytowała” minioną epokę.

8 Paralele między Przybyszewska a Kafka dostrzega K. Now o sielski (Walenie do bram. W zb.: Transgresje, t. 3, s. 135). Rozwinęłam ten wątek w tekście Literackie maszyny Franza Kafki i Stanisławy Przybyszewskiej (,Mały Format” 2018, nr 1. Na stronie: http://malyformat.com/2018/01/ literackie-maszyny-franza-kafki-stanislawy-przybyszewskiej/ (data dostępu: 24 VII 2018〉).

$\mathrm{Z}$ powodu tych trudności w ocenie wartości literackiej prozatorskiego dorobku S. Pr zy by s z ewskiej wydaje mi się, że publikacja jej noweli i opowiadań w tomie Cyrograf na własnej skórze $i$ inne opowiadania (Gdańsk 2015), opracowana przez zespół edytorski pod kierunkiem D. Bink ow s k i j, powinna jednak zostać opatrzona jakimś komentarzem krytycznym. Trudno bowiem bezdyskusyjnie zgodzić się $\mathrm{z}$ twierdzeniami, formułowanymi w wydawniczej notce znajdującej się na odwrocie książki, mówiącymi o tym, że: „skrzące się erudycją i niezwykle wnikliwe psychologicznie” opowiadania Przybyszewskiej, „przemawiając własnym głosem literackim”, pozwola jej wyjść „Z cienia sławnego ojca” i dowieść, że „niesłusznie skazano ją na zapomnienie”. Ostentacyjnie sztuczne, „splagiatowane”, elitarno-masowe opowiadania Przybyszewskiej nie bronią się same, wymagaja pewnego klucza lekturowego.

9 L. Ma gn o n e, „Święty Charlie Chaplin”. Wptyw doświadczeń kinematograficznych na prozę Stanisławy Przybyszewskiej. W zb.: Wspólnota wyobrażona. Pisarki Europy Środkowej wobec problemów literackich, społecznych i politycznych lat 1914-1944/45. Red. G. Borkowska, I. Boruszkowska, K. Nadana-S okołowska. Warszawa 2017. 
partiami dialogowymi, okazują się one precyzyjnie skonstruowanymi scenariuszami" ${ }^{10}$. Powtarzające się schematy fabularne i kompozycyjne rozwiązania, sposób szkicowania sylwetek postaci, budowania określonej atmosfery, a także kadrowania poszczególnych scen (gra światłem i cieniem, typowe przestrzenie, łączenie realizmu z projekcjami psychiki) świadczą o świadomym zapożyczaniu się pisarki zarówno w sferze wysokiej sztuki, jak i popkultury.

Prozie Przybyszewskiej - twierdzi Magnone - odmawiano artystycznej wartości, ponieważ oceniano ją z punktu widzenia kryteriów autonomicznej sztuki wysokiego modernizmu ${ }^{11}$. Tymczasem warto i należy spojrzeć na nie $z$ perspektywy modernizmu wernakularnego (pojęcie Miriam Bratu Hansen), polegającego na łączeniu obiegów wysoko- i niskoartystycznych, by stworzyć adekwatny język zmieniających się czasów, który pozwoli jednak „na odzwierciedlanie, odrzucanie, dezawuowanie, przekształcanie oraz negocjowanie traumatycznego wpływu nowoczesności" 12 . Najwyraźniej Przybyszewska uznała, że ludzki i zarazem nie-ludzki wymiar epoki mas i maszyn, gwałtownych napięć politycznych i rosnącego w siłę pieniądza lepiej wyrazić mogły ruchome, choć nieme obrazy, które jednocześnie wzbudzały w odbiorcach śmiech i grozę. Filmowy fenomen uwielbianego przez nią Charliego Chaplina - błazna, komedianta i bohatera głęboko tragicznego zarazem - najlepiej pokazywał ową dwukodowość dzieła wernakularnego ${ }^{13}$.

Jeśli więc Przybyszewskiej-prozatorce chodziło o uzyskanie efektu wernakularności, to znaczy, że ów wyczuwalny „błąd w sztuce” był zamierzony, a skaza - świadomym, choć może ironicznym, działaniem? Jej proza miała być jak nowoczesność, której narodziny bacznie obserwowała: ostentacyjnie sztuczna i monumentalnie melodramatyczna, nie zaś realistyczna czy tragicznie wzniosła.

Niewykluczone zatem, że dzieła prozatorskie pełniły w życiu twórczym Przybyszewskiej inną funkcję, niż się im przyznaje. Wbrew temu, co sugerowała Bojarska, nie były one wcale „produktami” przeznaczonymi na sprzedaż, lecz raczej polem do przeprowadzania ćwiczeń warsztatowych oraz szerzej zakrojonych eksperymentów. Ich cel stanowiło wypracowanie przez Przybyszewską takiej formy narracji, która odpowiadałaby jej osobliwemu (i zarazem hipernowoczesnemu) sposobowi patrzenia na świat i psychikę ludzką. W tym sensie utwory te nie były w ogóle dziełami w tradycyjnym rozumieniu - a więc zamkniętymi, dopracowanymi, skończonymi całościami, obiektami sztuki przeznaczonymi do kontemplacji. Świadczyłoby to, że woodzkie jako modernizm wernakularny. Przeł. Ł. Biskupski [i in.]. W zb.: Rekonfiguracje modernizmu. Nowoczesność i kultura popularna. Red. T. Maje wski. Warszawa 2009, s. 254. Autorka wykorzystuje tu istniejące słowo „wernakularny” w znaczeniu „natywny, swojski, rodzimy”, przekraczając jednak opozycję między tym, co w modernizmie lokalne, a tym, co globalne. Podkreśla ona w ten sposób znaczenie potocznego doświadczenia nowoczesności, które wytwarza estetykę modernizmu wernakularnego. W szerszym sensie wernakularność polega tu na celowym przenikaniu się obiegów sztuki wysokiej i popularnej, a także na łączeniu klasycznych form z nowoczesnymi tematami.

13 Postać Chaplina może być tu symbolicznym miejscem, w którym wernakularność spotyka się z awangardą. Zob. P. Stroże k, Charlie Chaplin - ikona awangardy. „Dialog” 2011, nr 9. 
należy je czytać jako zarys nieukończonego (i samodzielnie przygotowywanego) projektu awangardowego - pokrewnego idei Jana Brzękowskiego powieści filmowej $^{14}$ - który można by rozpatrywać w kontekście szerszego zjawiska w literaturze Dwudziestolecia, określonego przez Jerzego Kwiatkowskiego jako nurt nowatorskiej prozy sensacyjno-filmopodobnej ${ }^{15}$.

Byłby to jednak projekt nie tylko nieukończony, ale i obciążony wysokim ryzykiem artystycznym. Wydaje się, że Przybyszewska sama doskonale to wyczuwała: nie była zadowolona $z$ rezultatów swojej pracy, nie rezygnowała wszakże $z$ wytyczonej sobie drogi. Nie nazwałabym tego porażka, lecz istotnie Przybyszewskiej nie udało się zrealizować w prozie swoich literackich zamiarów - czy dlatego, że zawiódł ją warsztat? Czy też raczej pogodzenie estetyki popularnej z projektem awangardowym okazało się w praktyce niemożliwe? I czy kwestie genderowe były w jakikolwiek sposób uwikłane w te poszukiwania i zmagania artystyczne?

\section{Od ćwiczenia stylistycznego do laboratorium nowej prozy}

W liście do redaktora „Wiadomości Literackich” Mieczysława Grydzewskiego z roku 1927 Stanisława Przybyszewska, młoda adeptka sztuki pisarskiej, przyznaje się otwarcie do swojej nieumiejętności tworzenia short stories (L-1 120), a także do niechęci wobec tej formy literackiej. Choć w wielu innych miejscach wypowiadała się $z$ lekceważeniem o popularności samego gatunku, który w dobie ogromnego rozwoju prasy okazał się dla redaktorów świetnym biznesem, dla początkujących zaś autorów - albo przepustką do świata literatury, albo zapora nie do przejścia, to jednocześnie zdawała sobie sprawę, że sztuka pisania opowiadań „wymaga techniki wirtuoza” (L-1 120) ${ }^{16}$. To właśnie ten ambiwalentny splot doskonałej interesowności i warsztatowego mistrzostwa okazał się największym wyzwaniem na jej drodze rozwoju artystycznego. Przybyszewska nie lubi, nie chce i nie potrafi pisać opowiadań - i właśnie dlatego zaczyna to robić. W liście do Wacława Dziabaszewskiego czytamy:

Ponieważ jednak nie umiem pisać po ludzku opowiadań, więc wyznaczyłam sobie, jako robotę dodatkową, przygotowanie (oczywiście piśmiennie, atramentem, numerowane i spinane jak najsumienniejsza korespondencja handlowa) szkieletów noweli rozmaitych długości; tak aby materiał był ułożony w rozdziały, a treść każdego rozdziału najdokładniej podana. [L-1 325]

Zob. A. W ój t o w i c z, Wśród „nowych możliwości”. Powieść awangardowa i film. W: Cogito i „sejsmograf podświadomości”. Proza Pierwszej Awangardy. Lublin 2010.

J. Kw i t k ow s ki, Dwudziestolecie międzywojenne. Warszawa 2002, s. 271 n. Za reprezentującą ten nurt Kwiatkowski uznał inspirowaną filmem twórczość A. Ważyka, B. Jasieńskiego, J. Kurka, J. Brzękowskiego, a więc autorów związanych z Pierwszą Awangardą. Zob. też A. Giży c ki, Awangarda wobec kina. Film w kręgu polskiej awangardy artystycznej Dwudziestolecia międzywojennego. Warszawa 1996.

Wątek ten pojawia się również w postaci autotematycznych, ironicznych wtrąceń w niektórych opowiadaniach: „O wytęsknione kwiaty paproci, o niedosiężne szczyty, klucze wy srebrne do słonecznego raju, gdzie krew serdeczną stylografu na czeki się przetwarza - short stories, nie ma co prawda, lecz każdy gryzipiórek o was marzy - jesteście właściwie nie kluczem, lecz zręcznie ukrytą zapora z kolczastego drutu, wynalazkiem redaktorów, którzy w was znaleźli nareszcie skuteczny środek ochrony od szturmującej, głodnej młodzieży" (S. Przy by s ze w s ka, Pan En. W: Cyrograf na własnej skórze i inne opowiadania, s. 79). 
Przybyszewska męczy się i trudzi, z biegiem czasu twórczość prozatorska staje się dla niej najważniejszym testem jej umiejętności pisania. Zwierzając się ze swoich kłopotów z formą, często swoje zmagania przedstawia autoironicznie jako fizyczna walkę z potworem: „bestia rozpuchła się po horyzont, żre dzień po dniu pracy, wykręca mi rękę [...] i bardzo, bardzo gruntownie rozprasowuje moje wysokie o sobie mniemanie" (L-1 326). Wielotygodniowej harówce nad literackim przygotowaniem wybranego „szkieleciku” towarzyszy uczucie ,intensywnie cnotliwej nieprzyjemności" (L-1 327), nieprzyjemności, dodajmy, bezinteresownej: poza nie przyjętym przez Grydzewskiego fragmentem powieści Asymptoty, Przybyszewska nie wysyła nigdzie swoich prozatorskich tekstów, nie przestając ich jednak pisać. W ten sposób bowiem - jak uzasadniała - utrzymuje się ona w stanie „czuwania”, swoistego rozgrzania intelektualnego przed przystapieniem do komponowania dłuższych form (L-1 375). Przybyszewska przyjmuje w procesie twórczym postawę klasyka - o którym pisali Henry Peyre czy Ryszard Przybylski $^{17}$ - a więc kogoś, kto metodycznie dąży do zapanowania nad materią za pomocą wypracowanej konstrukcji, kto sam narzuca sobie ograniczenia, ceni trud oczyszczania, doskonalenia formy. Jest w tym zapewne mieszanina uległości i ambicji, skromności i dumy. Autorka Sprawy Dantona zgodziłaby się z twierdzeniem Paula Valéry'ego:

We wszystkich sztukach, gdzie materia sama przez się nie stawia wyraźnego oporu, prawdziwi artyści czują niebezpieczeństwo i nudę nadmiernej łatwości $\langle\ldots$. . Doznają niepokoju o trwałość tego, co tak mało ich kosztuje i co się rozwija tak łatwo ${ }^{18}$.

Dlatego też Przybyszewska wykonuje szereg ćwiczeń narracyjnych, tworząc schematy fabularne lub - jak twierdzi Magnone - „scenariusze filmowe”. Z listu do Iwi wiemy, że w 1930 roku ma tych „szkieletów” ponad 20. Wykorzystuje przy tym całkiem świadomie technikę przepisywania istniejących fabuł - zarówno filmowych, zaczerpniętych z kina awangardowego oraz popularnego, jak i literackich. Przybyszewska wprost mówi o „kompleksie plagiatorskim”, ujawniającym się zwłaszcza wobec tekstów ojca. Definiuje ów kompleks w ironiczny sposób albo za pomoca metafory kulinarnej „łakomienia się na niedowarzone produkty cudzej

17 H. Peyre, Co to jest klasycyzm? Przeł., posł. M. Żurows ki. Warszawa 1982. - R. Przy by ls ki, Tojest klasycyzm. Warszawa 1978. O nowoczesnym klasycyzmie Przybyszewskiej jako wybranej przez nia poetyce samoograniczenia i „dysocjacji” pisałam w pracy Stanisława Przybyszewska i nie-ludzka literatura (w: Arachne i Atena. Literatura, polityka i kobiecy klasycyzm. Kraków 2017).

18 Cyt. za: Peyre, op. cit., s. 123. Klasycyzm jest tu tym istotniejszym tropem, że również B ratu Hansen (op. cit., s. 240-242) pisze o typowym dla modernizmu wernakularnego połaczeniu klasycznej, dopracowanej formy z konwencjami popularnymi i nowoczesną tematyką, które doprowadziło do powstania kanonicznego wzorca filmu hollywoodzkiego. Co więcej, badaczka pokazuje, że ta klasyczna forma obrazowania (zwłaszcza zasada ciagłości montażowej, a także sposób kadrowania przestrzeni czy wykorzystywania emocji) została przyswojona przez reżyserów kina rewolucyjnego: „kino rosyjskie stało się kinem sowieckim, przechodząc przez proces amerykanizacji”. W tej przedziwnej fascynacji radzieckich twórców gatunkami niskimi i „filmowymi wątkami rodem z literatury brukowej” (W. Szkłowski) dopatrywano się przewrotnego ataku lewicowej awangardy na ideał „sztuki wysokiej”. 
kuchni” (L-1 328) ${ }^{19}$, albo jako „nieprzezwyciężona libido w stosunku do niedociągniętych tematów” (L-1 325) ${ }^{20}$, drażni ją bowiem literackie „partactwo”:

Gdy natrafię na powieść lub nowelę, zawierającą myśl lub motyw, do którego autor nie dorósł, który przez głupotę pominął lub wypaczył - wtedy trudno mi się wstrzymać od przebudowania danej rzeczy. [L-1 325]

Swój kompleks plagiatorski Przybyszewska nazywa dalej imieniem Thei von Harbou (L-1 325) ${ }^{21}$ - niemieckiej scenarzystki filmowej, żony Fritza Langa - która chwalona była przez polskich awangardystów za literackie, nie „faktograficzne” podejście do scenariusza filmowego. Tak to ujmował Anatol Stern:

Biegunowo innej metody trzyma się Thea von Harbou. Scenariusze jej czyta się jak powieści. Autorka nie ogranicza się do opisu faktów, ale stara się odtworzyć atmosferę sceny - stworzyć nastrój ucieka się częstokroć do środków literackiego impresjonizmu ${ }^{22}$.

Jednak dla Przybyszewskiej otwarta i bezpośrednia identyfikacja własnej twórczości z remake’owymi praktykami scenarzystki Langa, określanej przez nią wprost jako „idiotka”, ma inny, niewątpliwie autoironiczny charakter. Nie chodzi jej o osiągnięcie efektu psychologicznej bądź emocjonalnej prawdy, to raczej kategoria ostentacyjnego monumentalizmu czy melodramatyzmu, po jaką najchętniej sięgała Harbou, jak również sama metoda plagiatu wydaje jej się ciekawa. Przepisywanie cudzych tekstów jest dla Przybyszewskiej celową strategia „tworzenia przez przetworzenie", która uchyla pytanie (lub inaczej je stawia) o oryginalność i jej związek z doskonałością dzieła. Autorka Sprawy Dantona strategię tę stosuje kierując się nie tyle klasyczną zasadą emulacji ${ }^{23}$, ile raczej zasadą kompilacji, montażu, która - jak twierdził Peter Bürger - jest główną cechą dzieła awangardowego ${ }^{24}$. Idąc za tym badaczem, Jacob Wamberg odróżnia optymistyczno-utopijnych modernistów (reprezentujących rosyjski konstruktywizm, holenderski De Stijl czy funkcjonalizm Bauhausu) od przekornych antyutopistów awangardowych (dadaistów i surrealistów), którzy ironicznie podważają sensowność wszelkich zwartych konstrukcji.

Przybyszewska jest świadoma, że są to produkty nieudane i niesmaczne, z których może powstać coś, co nie przestanie nosić na sobie skazy niższości: „wyszukany, afektowany, błahy nonsens”, pretensjonalne dzieło kiczu, zniekształcone w samej swojej genezie.

Przybyszewska używa przekornie języka psychoanalitycznego, ironicznie przekształcając to, co seksualne i nieświadome, w to, co literackie i świadome. Wydaje się, że o wiele bardziej interesuja ją perwersje umysłu niż ciała.

21 Autorka Sprawy Dantona zapisuje jej imię z błędem (celowym?) jako „Trea von Harbou”.

22 A. St er n, Scenariusz - kronika serca. W: Wspomnienia z Atlantydy. Warszawa 1959, s. 83. Ważne jest również to, że Przybyszewska - w przeciwieństwie do Sterna czy Irzykowskiego - opowiadała się raczej za utrzymaniem odrębnej specyfiki sztuki filmowej. Nie ceniła więc zabiegów upodobniających film do literatury (lub dramatu), chciała raczej literaturę „ufilmowić”.

23 To, co odróżniałoby klasyczną emulatio od awangardowej kompilacji, to stosunek do „źródła”: w pierwszym przypadku chodziłoby o rozwinięcie dzieła Mistrza, prześcignięcie go w sztuce pisarskiej, w drugim o anarchistyczny asamblaż skradzionych komuś fragmentów. Przybyszewska ma złożony stosunek do kopiowanych fabuł: czasem korzysta z najlepszych, częściej wszakże z najgorszych wzorców, niektóre ceni, inne ją nudzą, jeszcze innymi wręcz gardzi. W efekcie jednak wydaje się, że dąży do połączenia klasycznej doskonałości $\mathrm{z}$ awangardowym montażem.

P. Bürger, Teoria awangardy. Przeł. J. Kita-H u be r. Kraków 2006. 
„Zamiast kreacji ex-nihilo mamy tu raczej skłonność do interweniowania, zawłaszczania, komentowania”, zamiast koherentnej kompozycji - „mechaniczny asamblaż części, które znajdują się w maszynie” 25 . Również polscy awangardyści zainteresowani stworzeniem powieści filmowej czy powieści-scenariusza wskazywali na konieczność rozbicia kompozycji (zwłaszcza fabularnej, opartej na zwiąkach przyczynowo-skutkowych) na poszczególne, luźno połączone ze sobą obrazy jako na najważniejszy obszar wytwarzania antymimetycznej, nowej sztuki ${ }^{26}$.

W prozie Przybyszewskiej odnajdziemy obie wspomniane tu tendencje jednocześnie: zarówno (awangardowy) montaż skradzionych motywów, jak i (konstruktywistyczną) precyzję w sposobie budowania fabuły. Być może, wiara w sens połączenia sprzecznych sił wytwórczych (de-kompozycji i re-kompozycji) stanowiłaby to, co odróżnia dzieło modernizmu wernakularnego od dzieła awangardowego, które wyrzeka się marzeń o ładzie i porządku? I być może to właśnie z powodu tego "zgrzytu” Bojarska zarzuciła pisarce brak konsekwencji artystycznej, która doprowadziła do zderzenia " dekobrycznego" przepychu irytująco sztucznej fabuły” $\mathrm{Z}$ „nieoczekiwaną doskonałością wykonania”27?

Postawa Przybyszewskiej wobec nowoczesności wydaje się nie mniej ambiwalentna. $Z$ jednej strony, pisarka nie ma co do niej złudzeń, jest krytyczną obserwatorką wczesnokapitalistycznej rzeczywistości, w której coraz większą przestrzeń zagarnia nacjonalizm i eksploatacyjna ekonomia kumulacji zysku. $Z$ drugiej - pokłada wielkie nadzieje w technologicznym postępie. Można chyba powiedzieć, że Przybyszewską fascynuje i przeraża kulturowa maszyna nowoczesności, z której czerpać będzie, komponując swoje fabuły. Intryguje ją zaś przede wszystkim to, jak owa nowoczesność jest stwarzana i jak sama stwarza nowe formy myślenia, odczuwania i widzenia świata.

\section{Spojrzenie kinematograficzne}

Jak pisze wspomniany Jacob Wamberg, a za nim kuratorki wystawy Superorganizm. Awangarda i doświadczenie przyrody, nowoczesność opanowała prawdziwa fascynacja zjawiskiem patrzenia. Od odkryć technologicznych, przez fizykę, chemię i medycynę, aż po filozoficzne i artystyczne projekty dojścia do tzw. czwartego wymiaru twórcy z początku XX wieku zainteresowani byli zarówno fizjologią wcielonego widzenia, jak i psychologią percepcji. To w tym właśnie kontekście możemy połączyć ze sobą tak różne, a jednak skupione na podobnych problemach, zjawiska i tendencje awangardowe: poszukiwanie czystej optyki w Bauhausie, prace holen-

J. W a m b e r g, Wejście $w$ drugą naturę. Technologia we wczesnym modernizmie i sztuce awangardowej. W zb.: Superorganizm. Awangarda i doświadczenie przyrody (katalog wystawy). Red. A. J a c h, P. K u r c-M a j. Łódź 2017, s. 244, 246. Wydaje się więc, że modernizm wernakularny idzie w poprzek tego podziału, który tym silniej wskazuje na elitaryzm awangardy jako modelu estetyki, domagającej się nieustannie odróżnienia od wszystkiego innego.

26 Zob. W ój tow i c z, op. cit., s. 215. Tendencja antyrealistyczna zaznacza się najsilniej w projektowanym przez J. Ku rk a (Jak się pisze scenariusz filmowy. „Ilustrowany Kurier Filmowy” 1928) modelu powieści-scenariusza. Zasada kolażu prowadzi w pierwszej kolejności do zanegowania fabuły jako zbyt mimetycznego elementu kompozycji.

27 B ojar s ka, op. cit., s. 118. Świadczyć to może raczej o tym, że Przybyszewska dążyła jednak do pogodzenia ze sobą klasycznej zasady emulatio $\mathrm{z}$ awangardową kompilacją. 
derskiej grupy De Stijl (inspirowane badaniami chemicznymi Wilhelma Ostwalda, dotyczącymi harmonii barw), niemiecką szkołę Nowej Rzeczowości, symultaniczno-synestezyjną teorię Michaiła Matiuszyna ZOR-WIED (widzieć-wiedzieć), a także powszechną fascynację ruchem i rzeźbą kinetyczną ${ }^{28}$.

Bratu Hansen, powołując się na znany esej Waltera Benjamina Dzieło sztuki $w$ dobie reprodukcji technicznej, wskazuje na kwestie historii i ekonomii postrzegania zmysłowego jako kluczowe pole walki o znaczenie i doświadczenie nowoczesności:

Rozprzestrzenianie się technologii miejsko-przemysłowych, masowe zerwanie więzi społecznych (i płciowych), przejście do masowej konsumpcji pociągnęy za sobą procesy realnego zniszczenia i utraty. Jednocześnie wykształciły one nowe sposoby organizacji widzenia i doświadczania zmysłowego, nowy stosunek do „rzeczy”, odmienne rodzaje doświadczenia mimetycznego, ekspresji, afektywności, czasowości i refleksyjności ${ }^{29}$.

Dla Przybyszewskiej również jej własne problemy z „produkcją prozy” dotyczyły zasadniczo kwestii widzenia - a więc tego wszystkiego, co wiąże się ze sposobem prowadzenia narracji. W trakcie pracy nad opowiadaniem Pasiphaë (która ma ją przygotować do podjęcia tematu procesu czarownic w powieści Labourd - remake’u Il regno doloroso Przybyszewskiego) wyznaje:

mój sposób pisania, choć się jako tako nakrywa z ogólnie przyjętym w formie dramatycznej - jest zasadniczo odmienny w beletrystyce od wszystkich, jakie znam. [...]

Mam bowiem percepcję zjawisk psychologicznych zanadto oryginalną, a przede wszystkim zanadto ostrą. Widzę każdy impuls, każdą myśl, źródła każdego czynu na kilku płaszczyznach równocześnie; i zbyt wyraźnie wiem, czym jest każda z tych płaszczyzn i jakie między nimi zachodzą związki. [L-1 375-376]

Można powiedzieć, że Przybyszewska posługuje się spojrzeniem kubistycznym, ogląda zjawiska psychiczne i fizyczne jednocześnie od wielu stron. Widzi je ostro (nazbyt ostro) i w ścisłym (nazbyt ścisłym) ze sobą połaczeniu. O ile - według niej - inne dziedziny sztuki (w tym dramatopisarstwo) wypracowały już środki artystyczne do oddania owej symultaniczności patrzenia, o tyle literatura wciąż nie ma dla nich odpowiedniej formy narracji. W liście do Iwi z 1929 roku z trzeźwym autokrytycyzmem stwierdza, że w prozie ma jeszcze wiele do poprawienia: „moja forma powieściowa nie dorównuje mojej (strasznie trudnej, poza tym z by t nowoczesnej) treści” (L-3 283). Przybyszewska przyznaje też niechętnie, że najbliżej byłoby jej do Proustowskiego wzorca prozy (niechętnie, bo Prousta szczerze nie znosiła), ale w przeciwieństwie do niego ona zmierza w stronę narracyjnego obiektywizmu i depersonalizacji (nie zaś subiektywizmu i personalizacji).

Wydaje się, że Przybyszewska, podobnie jak choćby Władysław Strzemiński, chciała oprzeć sztukę prozatorską na „świadomości wzrokowej”, która prowadzi do stworzenia konstrukcji totalnej, absolutnej, rozumowej, zrównoważonej i uniwersalnej. Nigdy nie chodziło jej o mimetyzm, prawdziwe przedstawianie rzeczywistości, lecz raczej o osiagnięcie takiego poziomu wglądu w postać czy zdarzenie, które zbliżałoby się do czystego, obiektywnego patrzenia przyrządu optycznego. To zaś wymagało od niej „pracy wprost matematycznej, czterech redakcji z mnóstwem 
brulionów do każdej, dyspozycji, podziałów czerwonym ołówkiem, etc." (L-1 376). Istotnie, Przybyszewska pracuje jak maszyna - co czyniłoby jej metodę twórczą bliską ideom konstruktywistów czy suprematystów - ale jednocześnie, niczym hollywoodzka „Fabryka Snów”, taśmowo produkuje kolejne, łudząco podobne do siebie „scenariusze” swej prozy.

Ta analogia nie jest, oczywiście, przypadkowa - kino bardzo szybko stało się „metaforą modernistycznych dylematów poznawczych”, a rozwój filmu uświadomił ludziom sztuki „konieczność stworzenia formuły gatunku wpisującej się w horyzont oczekiwań współczesnego odbiorcy oraz umożliwiającej opisanie jego nowoczesnej kondycji” ${ }^{30}$. Przybyszewska bardzo wcześnie zrozumiała, że nowoczesność będzie epoką ruchomego obrazu, a nowy sposób widzenia będzie wiązał się z wykształceniem innej wrażliwości wizualnej. Narzędziem tej zmiany stanie się zaś magiczny kintopp:

Byłam dni kilka temu w kintoppie (u Was się mówi podobno iluzjon) i jestem zbudowana. Wiesz, doprawdy jest w tym coś. (Może wyciaggasz stąd fatalne wnioski co do stanu mojej kultury). Przede wszystkim: dramat głupi sam w sobie jak nóżka od stołu, zupełnie bez pretensji do sztuki, a więc nie pachnie atramentem ani kombinacjami myślowymi. Naiwne to, jak commedia dell'arte. Przedstawiający grają dobrze i znowuż w zgoła nieartystyczny sposób. A rzecz najważniejsza to to, że się nic nie mówi. To nadaje przy szybkości akcji pewną wytworność nawet. No mówię ci, zachwycona jestem kintoppem. [L-1 42]

Ta wypowiedź z 1921 roku dowodzi świadomego wejścia w świat filmu jako ściśle określonej konwencji. Przybyszewska-kinomanka rozpoznaje naiwność kreowanej na oczach widzów iluzji, ale akceptuje ją jako celową formę kulturowej ekspresji. Sama zresztą przyznaje się do specyficznego osobistego i emocjonalnego sposobu odbioru filmu: „Jakże to lubię! Nie ma silniejszej przyjemności, jak podczas świetnie granej tragicznej sceny miąc w ręce program i ocierać spływające łzy" $(\mathrm{L}-1250)^{31}$. Przybyszewska daje się więc uwodzić filmowej fikcji, jednak najbardziej podoba jej się wytworne milczenie skontrastowane $z$ dynamiką przewijających się obrazów.

Nie zmieniło się to i później, w dobie udźwiękowiania produkcji, kiedy wprowadzone zostały dłuższe partie dialogowe, mające na celu wywołanie wrażenia większej naturalności i realizmu. Przybyszewska pozostała zwolenniczką sztucznej ciszy, a nie mimetycznego naśladownictwa przez obraz filmowy. Choć zasadniczo w literaturze sprzeciwiała się ekspresjonizmowi, w kinie - zarówno niemieckim, jak i radzieckim - docenia ten nowy rodzaj wrażliwości. Skrót naładowany symbolicznym znaczeniem, czyjeś doznanie zamknięte w doskonale zrobionej mikroformie,

Wójtowicz, op. cit., s. 191. W tym sensie nie ma różnicy między Przybyszewską a dążeniami awangardystów - uznają oni (w geście niejako bezinteresownym) konieczność wypracowania przez artystów formy mówienia adekwatnej względem doświadczeń nowoczesnego odbiorcy.

31 To właśnie afektywne podejście Przybyszewskiej do iluzji kinowej upodobnia ją - zdaniem Magnone - do panien sklepowych opisanych przez S. Kr a c a u e r a (Panny sklepowe ida do kina. Przeł. M. Ka r k ow s ka. W zb.: Rekonfiguracje modernizmu). Z drugiej strony, badaczka słusznie zauważa zasadniczą odmienność stylu odbioru filmów (nawet tych popularnych), ironiczny krytycyzm Przybyszewskiej wobec konwencji filmu amerykańskiego, powodujący, że nie można jej gustu uznać za popularny. W ciemnej sali kinowej pisarka nigdy nie doznaje uczucia wspólnoty z innymi widzami. 
mówienie obrazami, nie pojęciami ${ }^{32}$. W tym sensie Przybyszewska myślała o filmie tak samo jak Tadeusz Peiper, który odrzucał kryterium mimetyczności na rzecz „ekranowości” 33 . Nie epicki opis, lecz sekwencja obrazów, nie realistyczny detal, lecz abstrakcyjny lub ekspresyjny skrót. Estetyka filmu wydała się Przybyszewskiej - podobnie zresztą jak awangardystom - językiem nadchodzącej przyszłości. W roku 1931 w liście do niemieckiego tłumacza Josepha Heinza Mischela $z$ właściwą sobie nonszalancja pisała: „od czasu, gdy porównałam film ze sceną i nad tym porównaniem się troszkę zastanawiałam - przestałam scenę traktować poważnie” (L-2 385).

Przybyszewska nie jest jednak nigdy konsekwentnie awangardowa, raczej zgodnie $z$ poetyką modernizmu wernakularnego dąży do przemieszania, połączenia sprzecznych porządków estetycznych czy zasad kompozycyjnych. Toteż w przedziwny sposób w jej prozie wizyjność sąsiaduje $z$ nadmierną, zbyt drobiazgową opisowością, rzeczywistość z koszmarem sennym lub halucynacją.

Spójrzmy na dwie sceny z Asymptot ${ }^{34}$ - najbardziej filmowej z powieści Przybyszewskiej - które muszę bardziej opowiedzieć, niż zacytować ze względu na kilkustronicową rozwlekłość. Pierwsza $z$ nich to przypadkowe spotkanie trójkąta romansowego. André i Luko (Charles) zajęci są rozmową o Bernanosie (rozmowy o sztuce, literaturze są częstym motywem dialogów protagonistów). Nina siedzi z nimi przy jednym stole. Nagle przysuwa platynową bransoletkę do srebrnej łyżeczki, aż metal ociera się o metal.

Zaabsorbowana całkowicie patrzyła przez chwilę na martwe - pozornie - zestawienie; potem - zdjęła ruchem dziwacznie rozmyślnym pierścień $\mathrm{z}$ wielkim opalem, oprawnym $\mathrm{w}$ matową platynę, by go przyłożyć do pierwotnej kombinacji. [A-1 211]

Dokłada jeszcze kolejny element - złotą zapalniczkę, i przygląda się jak zahipnotyzowana tej grze obrazów.

Myśl jej, opuściwszy pośrednią drogę pojęć i abstrakcji, znalazła sobie najprostszą linię lotu: wyobrażenia wizualne. [...] widziała wielką płytę stalową, ujętą w ramę jawnie ołowianą. W płytę wpuszczono nieregularnie mniejsze płytki miedzi, tworzące rodzaj chaotycznego, barbarzyńskiego ornamentu... $[\mathrm{A}-1212]^{35}$

Wreszcie przed oczami Niny rozpościera się istna orgia materii zamkniętej w geometrycznych kształtach: srebrnych trójkątów, poprzecinanych liniami z platyny, usianych plamkami z cyny. Ta senna wizja przywodzi jej na myśl kształt własnych piersi - metal, klejnoty, ciało, znowu stożki. „Dziwaczny głód metali

Opozycji obrazu i pojęcia używał A. Ste rn (Polska „Myszeis” kinematograficzna. Uwagi o naszych reżyserach, scenarzystach, aktorach i krytykach filmowych. W: Wspomnienia z Atlantydy, s. 152).

T. P e i p e r, Autonomia ekranu. W: Tędy. - Nowe usta. Kraków 1972, s. 228.

34 Archiwum PAN. Oddział w Poznaniu. Mpis, sygn. PAN P-III-52 a, teczki 21-22 (teczka 21 zawiera cz. 1, teczka 22 - cz. 2). Do cytatów z Asymptot odsyłam skrótem A. Pierwsza liczba po skrócie, po łączniku, wskazuje część, następna - stronicę maszynopisu.

35 Podobna geometryczna halucynacja znalazła się w powieści i scenariuszu J. B r zę k ow s ki e go Kobieta i koła z 1931 roku. W Asymptotach matematyczna wyobraźnia odgrywa rolę istotnego czynnika estetycznego, podobnie jak wiszące na ścianach mieszkań reprodukcje obrazów Kandinsky'ego. 
zniknął bez śladu. Nina widziała - a raczej przeżywała - teraz siebie samą. [...] Myśl jej przekształciła się w wyobrażenie geometrycznego niemal kształtu” (A-1 213). Dziewczyna doświadcza czegoś w rodzaju ekstazy, orgiastycznego stanu dotknięcia jakiegoś absolutu, choć żaden z rozmawiających mężczyzn nie zauważa tego, co się $\mathrm{z}$ nią dzieje.

Druga ze scen to moment, gdy Luko (Charles) chce zemścić się na żonie Edzie za własne życiowe niepowodzenia i przypomina mu się miniatura $z$ hermafrodyta, która niegdyś kobieta mu podarowała. Wraz ze wspomnieniem nasila się „obraz pewien, przybierajacy stopniowo kontury ostre jak przedmiot widziany z zewnatrz [...]. Nie była to halucynacja - wiedział, że to tylko cień myśli podświadomej” (A-1 143).

To, co sam mimo woli wywołał i wymodelował w powietrzu, było alegoryczna grupa, przypominająca nagrobki szlachty wiejskiej, niezgrabnie ciosane na niezmienny motyw. Widział siebie jako smukłego rycerza - lecz w stroju sportowym do gry w golfa zamiast zbroi - stojącego z rozkraczonymi nogami $\mathrm{i}$ - ten jeden szczegół nie zgadzał się $\mathrm{z}$ wzorem - z rękami dumnie wspartymi na biodrach - a pod każdą z dość oddalonych od siebie stóp miał lewka lub raczej lwicę. [A-1 143]

Lwiczki zdychają, jedno oko mają otwarte i wzniesione błagalnie w stronę Luki. Ta groteskowa wizja pojawiająca się przed oczami bohatera za chwilę ustapi miejsca obrazowi cierpiącego mikroba, którego bada w laboratorium jego żona-mikrobiolożka, i to z nim mężczyzna zaczyna się silnie utożsamiać. Na koniec wracają do niego wspomnienia $z$ okopów wojny: ,jakieś kości, włosy, jelita i mięso zmieszane z gałganami i błotem”. Obok żywy, „żracy coś”, człowiek, koło niego „wzdęte zwłoki zatrutego szczurka” (A-1 146). „Nie otwierając ust - Charles zawył” (A-1 146). Podobnych scen ukazujacych męskie ataki histeryczne, spowodowane najczęściej traumą wojny, znajdziemy u Przybyszewskiej wiele.

Owe wizyjne obrazy, które mogłyby funkcjonować jako samodzielne miniatury, niepostrzeżenie wkradają się w przeważnie realistyczny, nowoczesny świat tej prozy, wytrącając fabułę z rytmu. Najczęściej wprowadzają efekt obcości, dziwności, groteskowości czy niesamowitości w znaczeniu Freudowskim. Sposób, w jaki są one komponowane, wskazuje wyraźnie na inspirację awangardową poetyką filmu. Przybyszewska posługuje się w nich techniką przenikania obrazów - chwytem używanym początkowo do „budowania nastroju grozy i niesamowitości”, który „u progu lat 20. za sprawą Louisa Delluca stał się środkiem umożliwiajacym ukazanie dotychczas niemożliwych do przedstawienia: "ukrytych myśli bohaterów [...] «", stanów, lęków, wspomnień, przeczuć ${ }^{36}$. Sięgnięcie po taką stylistykę zakłada odwołanie się do kompetencji odbiorcy nie tylko obdarzonego wyobraźnią czy wrażliwością wizualną, ale również obeznanego z określonymi konwencjami i technikami filmowymi.

Pisarka wykorzystuje przy tym dwie filmowe zasady komponowania: regułę podobieństwa (i przekształcania się jednej formy w drugą) - w pierwszym fragmencie, oraz asocjacji (łączenia ze sobą odległych wyobrażeń) - w drugim. Powstaje specyficzny efekt symultaniczności: choć obrazy następują płynnie po sobie, raczej przechodzą jedne w drugie, przenikają się nawzajem, istnieją równocześnie względem rzeczywistości obiektywnej, w której dzieje się coś innego. Oprócz XX-wiecz- 
nego malarstwa modernistycznego, $z$ którym Przybyszewska była zaznajomiona (także dzięki matce malarce), to właśnie estetyka filmowa stanowiła dla niej najważniejsze źródło inspiracji do narracyjnych i technicznych eksperymentów $z$ symultanicznością.

\section{Nie dość masowa, nie dość awangardowa (nie dość kobieca?)}

Kazimiera Ingdahl słusznie, moim zdaniem, polemizuje z tezą o osobności Przybyszewskiej na mapie polskiego Dwudziestolecia, łącząc pisarkę z szerokim nurtem europejskiego modernizmu. Badaczka ma tu na myśli dążenie do zniesienia opozycji między życiem a sztuką, jak też radykalny postulat uczynienia własnego ciała swoistym terenem do przeprowadzania eksperymentów artystycznych ${ }^{37}$. A jednak w jakiś dziwny sposób język, jakim posługuje się Przybyszewska, wydaje się nienowoczesny czy raczej anachroniczny ${ }^{38}$. Jej proza nie przypomina prowokacyjnie ironicznych i graficznie zdekomponowanych, awangardowych powieści Jana Brzękowskiego (choćby Bankructwa Profesora Muellera), nie będąc jednocześnie literatura popularną, którą chciałyby się zaczytywać stenotypistki i kucharki. Ta niekonsekwencja wynika częściowo $z$ tego, że, mimo ostentacyjnej sztuczności przejawiającej się choćby w partiach dialogowych i języku, autorka Asymptot nie odrzuciła zupełnie realizmu i fabularności - chciała zachować literacką wartość detalu, materialnego konkretu oraz znaczenia samej opowieści o losach swoich bohaterów. Jej stosunek do postaci był jednak również naznaczony ambiwalencją. W liście do Iwi żali się: „Dlaczego ja nie potrafię, kiedy piszę powieść albo nowelę, traktować jej poważnie? Jeśli czytam to, co napisałam, to po każdej stronie połyskuje to samo, cyniczno-apologetyczny uśmiech [...]" (L-3 125). Z biegiem czasu to się nieco zmienia, ale zawsze przy czytaniu prozy Przybyszewskiej wyczuwa się odautorski dystans wobec kreowanej fikcji: nie tyle ironiczny, ile cyniczny właśnie. W efekcie wydaje się, że w stosunku do opowiadanej historii stać jej narratorów co najwyżej na złośliwą drwinę lub śmiertelną powagę, nigdy zaś na szczery humor.

Być może, dlatego bohaterowie tej prozy wydają się tak „płascy” i tak uparcie nowocześni. Zwłaszcza kobiety przypominaja, z jednej strony, modernistyczne figury na płótnach Tamary Łempickiej, z drugiej - mechaniczne femmes fatales z nielubianego przez Przybyszewska Metropolis Langa. To self-made women, obdarzone rysem arystokratyzmu. Sa monumentalne, zawsze piekielnie inteligentne, piękne i silne, niezależne, niewzruszalne, niczym starożytne boginie-dziewice przeniesione w czasy stalowych maszyn. Naukowczynie, artystki, bizneswomen, stenotypistki, ekskluzywne kurtyzany, pisarki - swoją nowoczesnością imponują mężczyznom, którzy, choć zwykle równie racjonalni, nowocześni i ascetyczni, naznaczeni sa piętnem tragicznego zranienia. Doświadczenie pierwszej wojny (lub, jak w utworach historycznych, innej, podobnej formy masowej przemocy) oraz fizycznej

K. In g d a h 1, A Gnostic Tragedy. A Study in Stanisława Przybyszewska's Aesthetics and Works. Stockholm 1997.

38 Co ciekawe, jedyne wydane przed 2015 rokiem opowiadanie Przybyszewskiej - Ostatnie noce ventôse'a - spotkało się właśnie z negatywnym przyjęciem krytyki, która zarzuciła autorce uprawianie stylistycznej „młodopolszczyzny”. 
eksploatacji człowieka w dobie wczesnego kapitalizmu wytwarza histerycznych mężczyzn i opancerzone kobiety, próbujących przeciwstawić się (na próżno) nędzy wszystkiego, co żyje.

Motywem fabularnym, po jaki sięga Przybyszewska najczęściej, jest motyw faustyczny i hiobowy zarazem. Mimo iż jej bohaterowie uwikłani są w walkę ze sobą - nie tylko w rozgrywkę miłosną, ale też w konflikt „wyższego” $\mathrm{z}$ „niższym”, tego, który ma siłe pokonać życie oraz tego, który zostanie pokonany - to rozwiązania fabularne wskazują, że pisarka przedstawia historię jednakową dla wszystkich. To opowieść o nowoczesnych ludziach, ich pragnieniach i lękach, ludziach, którzy nie poradzą sobie - mimo siły, woli, inteligencji, bogactwa, miłości - z niepewnością, kruchością samego życia. Choć przez chwilę wydają się nadludźmi, kończą zwykle jak nieludzie: samobójcy, mordercy, prostytutki, skazańcy. Niewiele utworów Przybyszewskiej ma formalne zakończenia, ale te, które znamy, pozwalają przypuszczać, że ze wszystkich konwencji filmowych czy literackich - to właśnie konwencja happy endu była przez nią najbardziej znienawidzona.

Takie przeciwstawienie się przez Przybyszewską sile schematów fabularnych typowych dla twórczości popularnej mówi wiele o jej filozofii życia i tworzenia. Istotnymi składnikami jej projektu artystycznego i egzystencjalnego były cyniczny (w znaczeniu starożytnym, nie potocznym) sceptycyzm i antynaturalizm. Analizując konwencje powieści masowej, Umberto Eco zwrócił uwagę na funkcję zakończenia, które opiera się na „naturalnym mechanizmie pocieszycielskim”, będącym uspakajającym powtórzeniem powszechnie uznawanego systemu wartości ${ }^{39}$. Przybyszewska-prozatorka zachowuje się inaczej: jak przekorny popsuj-zabawa (killjoy), który rzeczywiście psuje wszystkim nastroje dokładnie wtedy, gdy wydawało się, że szczęście jest już tak blisko. Śmierć Luki pod kołami pociągu, w którym Eda i jej kochanek jada, by zacząc nowe życie, jest w Asymptotach ewidentnie formą odegrania się i ten motyw „zemsty słabych” będzie powracał nieustannie w innych opowiadaniach (choćby w Wybrańcu losu, Sterilitas czy Nie morderca winien). Warto dostrzec pewien paradoks: Przybyszewska chce posłużyć się formą tak dopracowaną, że wyklucza ona jakąkolwiek przypadkowość, by powiedzieć coś o nowoczesnym świecie pełnym bezsensownej i bezlitosnej przypadkowości. Jej literacka „fabryka snów" zamiast bajkowych obrazków produkuje senne koszmary, takie zresztą, o których można było przeczytać w faits divers.

Awangardyści inspirowali się filmową poetyką montażu, by uwolnić literaturę od ograniczeń realizmu, fabularności i psychologizmu, z którym kojarzone było kino popularne. Jak przyznaje Aleksander Wójtowicz:

W postulat stworzenia „liryzmu wzrokowego”, czyli awangardowego filmu eksperymentalnego, było wpisane przekonanie o elitarnym charakterze tej formy wyrazu, znajdującej się na antypodach kina komercyjnego ${ }^{40}$.

U. E c o, Superman w literaturze masowej. Powieść popularna: między retoryka a ideologia. Przeł. J. Ugniewska. Warszawa 1996.

40 Wójtowicz, op. cit., s. 194. Jest to szczególnie widoczne w pochwale filmu abstrakcyjnego wyrażanej przez J. Ku rka (O filmie „artystycznym” $i$ „stosowanym”. W zb.: Walka o film artystyczny w międzywojennej Polsce. Red. M. Giży c k i. Warszawa 1989, s. 138-140), który umieszczał film artystyczny w opozycji do popularnego. 
Również w „literaturze filmopodobnej” środkiem do osiągnięcia autonomii prawdziwego dzieła sztuki było odrzucenie fabularności jako zasady kompozycyjnej. Przybyszewska nie zanegowała znaczenia schematu fabularnego, chciała go raczej wykorzystać na swój własny sposób przez jego demontaż, remake, przepisanie. Dążyła do połączenia tego, co powtórzone, z tym, co idiomatyczne. Być może, najbliższa byłaby jej strategia tworzenia powieści filmowych przez Brzękowskiego, który jednak integralną częścią ich kompozycji uczynił (auto)ironię.

W moim przekonaniu brakowało Przybyszewskiej właśnie owej radosnej i burzycielskiej ironii awangardystów (dadaistów czy futurystów), która wzięłaby w nawias grę $z$ konwencjami sztuki zarówno wysokiej, jak i masowej ${ }^{41}$. Tymczasem, choć wydaje się, że autorka Asymptot manifestuje lekceważenie dla schematów fabularnych, które kradnie, swoją pracę „ulepszania” traktuje śmiertelnie poważnie. Zupełnie jakby chciała połączyć, mimo wszystko, klasyczną emulatio $\mathrm{z}$ awangardową zasadą kompilacji. Dlatego też nie rezygnuje z prozatorskich ćwiczeń, szlifując formę. Gdy awangardyści poddają świat przekornej dekompozycji - ona konstruuje swój w znoju i trudzie. Mimo iż pisze w postulowanej przez Brzękowskiego poetyce „heterogeniczności stylistycznej”, posługując się cytatami i kliszami, nie potrafi (a może nie chce) stworzyć sobie ironicznego „alibi”, które pozwoliłoby czytać jej teksty w poetyce pastiszu, parodii, trawestacji czy burleski. Nie sposób interpretować opowiadań Przybyszewskiej jak Opętanych Gombrowicza.

Wydaje się, że autorka Cyrografu na własnej skórze wierzyła do końca w możliwość wykreowania czegoś, co nazwałabym dzi ełem sztuki masowej-co nie stanowiłoby ani autonomicznego arcydzieła, ani też „dobrze skrojonego” utworu literatury popularnej. Prawdziwym zamiarem Przybyszewskiej było stworzenie takiej prozy, która posłużyłaby się popularnym schematem fabularnym, ale była doskonała w formie i wywrotowa w treści. Być może, to kwestia czasu, sił witalnych, środków do życia, których pisarce po prostu zabrakło, by doprowadzić swoją laboratoryjną pracę do końca? Może jednak zgrzyt w jej „maszynie literackiej” nastąił również $\mathrm{z}$ genderowego powodu?

Trudno nie zauważyć pewnych problemów, które prozatorski projekt Przybyszewskiej mógł napotkać ze względu na utrwalony w krytyce literackiej stereotyp kobiecego pisania. Najistotniejszym składnikiem tego wyobrażenia było przeświadczenie o wtórności, nieoryginalności, receptywności sztuki uprawianej przez kobiety oraz jej uległości wobec popularnego gustu, sezonowych mód czy utartych schematów $^{42}$. Strategia Przybyszewskiej pisania poprzez plagiat, choć śmiała i awangardowa, mogła się więc wydać niczym innym, jak tylko nieudolną próbą naśladownictwa, jej zaś inspirowane filmem poszukiwania nowoczesnej formy widzenia świata i człowieka - jedynie koniunkturalizmem. Wyraźne opowiedzenie się

41 Również Wój tow ic z (op. cit., s. 202) zwraca uwagę na ironię wewnątrztekstowa jako element kompozycji utworów awangardowych w typie Bankructwa Profesora Muellera J. Brzękowskiego. Pastisz i parodia okazują się tu pewnym „alibi” dla podjętej gry stylistycznej.

42 Kwestia ta jest dobrze opisana w krytyce feministycznej. Zob. K. Kł o s iń s k a, Kobieta autorka. W zb.: Ciało i tekst. Feminizm w literaturoznawstwie - antologia szkiców. Red. A. N a s ił o w s k a. Warszawa 2001. - J. Krajewska, „Jazgot niewieści” i „męskie kasztele”. Z dziejów sporu o literaturę kobieca w Dwudziestoleciu międzywojennym. Poznań 2010. 
po stronie racjonalizmu, konstruktywizmu i „obiektywnego psychologizmu” - jakkolwiek podważało genderowy stereotyp kobiecego pisania jako niekontrolowanego aktu biologicznej niemal ekspresji - właściwie wyłączało Przybyszewską z nurtu kobiecej „rewolucji artystycznej” ${ }^{43}$. Umiejscowiona gdzieś między nowoczesnym klasycyzmem - modernizmem wernakularnym a awangarda, proza Przybyszewskiej z trudem mieści się także na mapie kobiecego Dwudziestolecia. Choć jednocześnie ujawnia ona - również od strony formalnej - fundamentalne znaczenie opozycji „wysokiego” i „niskiego”, z która sztuka kobiet musiała zmagać się właściwie od początku istnienia debaty na temat związków literatury i płci.

Abstract

MONIKA ŚWIERKOSZ Jagiellonian University, Cracow

IN SEARCH OF A NEW VIEW STANISŁAWA PRZYBYSZEWSKA'S PROSE BETWEEN AVANT-GARDE AND VERNACULAR MODERNISM

The text formulates a question about Stanisława Przybyszewska's prose interpretive potential in the perspective of vernacular modernism (Miriam Bratu Hansen) and an avant-garde project of "film novel" (Jan Brzękowski). Considering Przybyszewska's inspirations from both popular cinema (early Hollywood) and avant-garde one (German expressionism and Soviet revolutionary movie) as well as the strategy of "plagiarism" of which she took advantage, the author of the paper underlines the problematic for modernity connection of high and low forms of culture. She also comprehends Przybyszewska's unfinished prose pieces as avant-garde laboratory of new modes of simultaneous seeing. Ultimately, she questions for a gender aspect of Stanisława Przybyszewska’s narrative quests. międzywojennym. Warszawa 2014. 